\section{Management of dental unit waterline biofilms in the 21 st century}

Mary J O'Donnell', Maria A Boyle', Ronnie J Russell² \& David C Coleman ${ }^{\dagger 1}$

'Microbiology Research Unit, Division of Oral Biosciences, Dublin Dental University Hospital, University of Dublin, Trinity College Dublin, Dublin 2, Republic of Ireland

${ }^{2}$ The Department of Microbiology, The Moyne Institute of Preventive Medicine, University of Dublin, Trinity College Dublin, Dublin 2, Republic of Ireland

†Author for correspondence: - Tel.: +353 16127276 = Fax: +353 16127295 = david.coleman@dental.tcd.ie

Dental chair units (DCUs) use water to cool and irrigate DCU-supplied instruments and tooth surfaces, and provide rinsewater during dental treatment. A complex network of interconnected plastic dental unit waterlines (DUWLs) supply water to these instruments. DUWLs are universally prone to microbial biofilm contamination seeded predominantly from microorganisms in supply water. Consequently, DUWL output water invariably becomes contaminated by high densities of microorganisms, principally Gram-negative environmental bacteria including Pseudomonas aeruginosa and Legionella species, but sometimes contain human-derived pathogens such as Staphylococcus aureus. Patients and staff are exposed to microorganisms from DUWL output water and to contaminated aerosols generated by DCU instruments. A wide variety of approaches, many unsuccessful, have been proposed to control DUWL biofilm. More recently, advances in biofilm science, chemical DUWL biofilm treatment agents, DCU design, supply water treatment and development of automated DUWL biofilm control systems have provided effective long-term solutions to DUWL biofilm control.

Microbial biofilms have a critical role in healthcare-associated infections, in particular, infections linked to medical devices and equipment. Medical devices implanted in the body either permanently or for extended periods of time, such as intravascular catheters, urinary catheters and orthopedic appliances, are the most significant in this respect [1]. However, many other medical devices have been identified as significant causes of infection and cross-contamination, especially in healthcare facilities [2-4]. Medical devices or components that are wet or moist are particularly prone to biofilm growth and are frequently linked with cases of infection.

In dentistry, the dental chair unit (DCU) is the most essential item of equipment necessary for the practice of dentistry [5] and is classified as a medical device according to the European Union Medical Devices Directive [6]. Over the last 40 years, the function of the DCU has developed from simply providing physical support to advanced designs and configurations that are comprised of several complex, integrated equipment systems, which provide all of the services (e.g., water, air supply, electric power and suction) and dental instruments required for a wide range of dental treatment procedures [5]. Dental instruments connected to DCUs (e.g., ultrasonic scalers, air scalers, high-speed turbine dental handpieces, and conventional dental handpieces) are cooled by DCU-supplied water, which also supplies threeway air/water syringes to irrigate and cool tooth surfaces during dental treatment. Heat generated by instruments can be harmful to teeth [7]. In addition, water is also supplied to the DCU cup filler outlet that is used by patients for oral rinsing and to the bowl-rinse outlet that rinses the DCU spittoon. Each DCU is equipped with an elaborate loom of interconnected narrow-bore (i.e., mostly $2-3 \mathrm{~mm}$ internal diameter) flexible plastic tubing called dental unit waterlines (DUWLs) that supply water to all of the DCU-supplied instruments, cup-filler and bowl-rinse water outlets [3,5]. In a typical DCU, the DUWL network can consist of many meters of tubing. Due to the texture and composition of the plastic tubing, microbial biofilms form readily, resulting in DCU output water that is frequently heavily contaminated with microorganisms. This problem was first identified almost 50 years ago, but is still significant today. Figure 1 shows an electron micrograph of dense biofilm on the internal surface of DUWL tubing from a DCU. The purpose of this article is to succinctly review the problem of biofilm contamination in DUWLs, its causes, the approaches that have been used to control the problem, and their strengths and

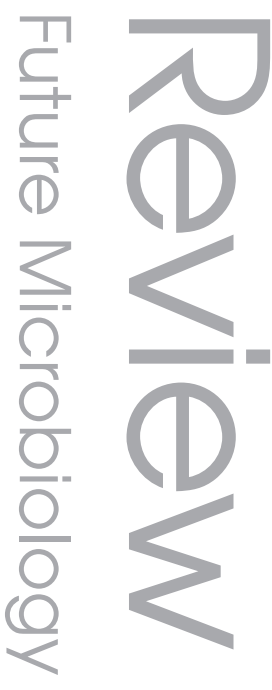

\section{Keywords}

- aerobic heterotrophic bacteria $=$ biofilm $=$ biofilm management $=$ contaminated aerosols $\mathbf{m}$ dental chair water quality $=$ dental unit waterlines - electrochemically activated solutions $=$ endotoxins

- environmental bacteria

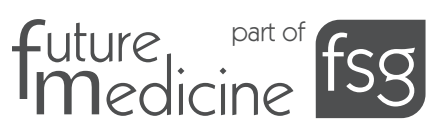




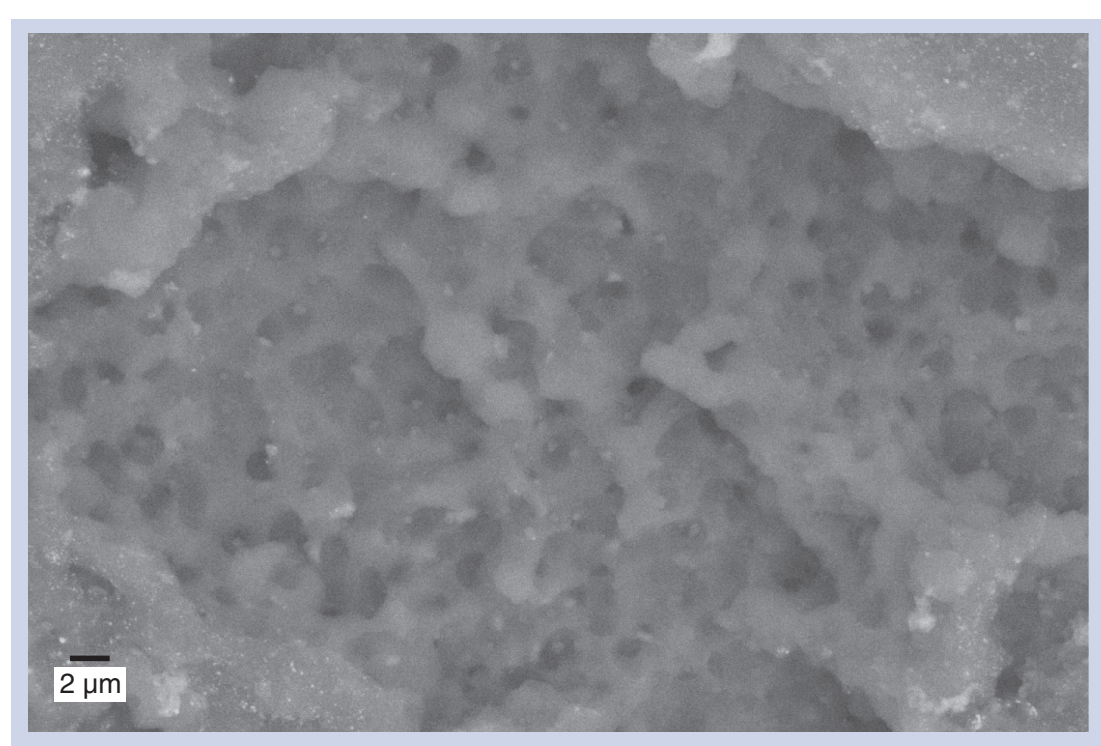

Figure 1. Electron micrograph of 4-week-old biofilm formed on the internal surface of a dental unit waterline taken from a dental chair unit supplied with potable quality mains water. The biofilm reached a thickness of $30 \mu \mathrm{m}$ after 4 weeks growth. to a maximum along the centerline of the waterline lumen. A thin immobile layer of fluid, called the hydrodynamic boundary layer, exists at the interface of the lumen wall and the moving water within the DUWL [34]. Following connection to a water supply, a conditioning pellicle or film of inorganic and organic chemicals from the water is gradually deposited on the lumen surface of DUWLs [35,36]. Microorganisms in DCU supply water, especially bacteria, on entering the hydrodynamic layer, adhere to the conditioning pellicle through weak, reversible van der Waals forces and afterwards attach themselves more permanently by other cell attachment and adhesion mechanisms. Adherent, early colonizers in the DCU supply water provide more diverse adhesion sites for other microorganisms, called secondary colonizers, which also commence growth themselves, giving rise to microcolonies. Almost immediately, attached cells and microcolonies begin to secrete complex polymers into the surrounding environment. This phenomenon is characteristic and essential for biofilm formation [34]. A wide variety of bacteria, especially environmental bacterial species, are able to secrete exopolysaccharides during biofilm formation, which contributes to cell protection against adverse environmental conditions, and aids attachment to surfaces and nutrient acquisition. These exopolysacchairdes are insoluble although highly hydrated and help to shield the microorganisms from being dislodged. Over time, this gives rise to a biofilm consisting of polysaccharide matrix-harboring individual cells and microcolonies [34]. Biofilms are highly structured microbial communities that exhibit complex intracellular communication via biochemical signaling, where cell phenotypes and function can vary significantly $[34,37,38]$. Biofilms resist penetration by a wide range of chemical agents including detergents, disinfectants such as chlorine, and antibiotics and other antimicrobial agents [34]. Biofilms that develop under laminar flow conditions, such as in DUWLs, have been found to be patchy and consist of rough round cell aggregates interspersed heterogeneously by interstitial voids or channels through which water can flow $[34,39]$. These channels provide a route for circulating nutrients, dissolved oxygen and metabolic products, and also provide a communications highway for the microbial community. The external surface layer of microorganisms in biofilm grow rapidly and some of these differentiate into robust planktonic (free-living) cells designed to travel and initiate new biofilms. During DCU operation, the shear force generated within DUWLs detaches pieces of biofilm 
along with planktonic forms of microorganisms. These can be deposited directly in the mouths of patients, can seed biofilm growth at other sites within the waterline network, or can be aerosolized and subsequently inhaled into the respiratory tracts of patients and dental staff when dynamic dental instruments such as ultrasonic scalers are used [3,5,22,25,40-43]. Consequently, DUWL biofilm functions as a reservoir for continuous contamination of DUWL output water. Microbial contamination of DUWL output water is a universal phenomenon in standard DCUs and all untreated DUWLs in DCUs will harbor resident biofilms and yield contaminated output water. Biofilms can form within the DUWLs of new DCUs within several hours of connection to a mains supply [44,45].

\section{Water stagnation}

Water stagnation in DUWLs, when DCUs are not in use, further encourages the growth of biofilm. Most DCUs are probably not used for more than $12 \mathrm{~h}$ per day, 5 days per week and thus water stagnation is a significant contributory factor to DUWL output water contamination.

\section{Heating of DCU output water}

Individual DCU models may come equipped with a water heating unit that provides DUWL output water at a temperature that is comfortable for the patient [5]. Heating DUWL output water to $>20^{\circ} \mathrm{C}$ may selectively encourage the growth of particular bacterial species. Examples include Legionella pneumophila (the most common cause of Legionnaire's disease and Pontiac fever), which readily proliferates at temperatures between 25 and $37^{\circ} \mathrm{C}$ and Comamonas acidovorans, an opportunistic pathogen of immunocompromised patients $[46,47]$. Legionella bacteria have often been reported in DUWL output water. DCUs should not be equipped with water heaters unless effective DUWL biofilm control systems or protocols are also present [5]. Recent studies in the authors' laboratory indicate that the temperature of DUWL water in DCUs can rise significantly following several hours continuous DCU use, probably owing to heat transfer from both the dental clinic environment and from internal DCU components [BoyLe M \& Coleman D, Unpublished Data] .

\section{Antiretraction valve failure}

Dental instruments that are attached to DCUs and connected to DUWLs (e.g., ultrasonic scalers, turbine and conventional handpieces and three-in-one air/water syringes) should be equipped with integrated antiretraction devices (usually valves) that prevent backflow of fluids from the oral cavity into DUWLs during instrument use [5]. However, a number of studies have shown that oral fluids can be retracted into DUWLs during dental instrument use [48-50]. Furthermore, the detection of blood, oral bacteria and other microorganisms of human origin in DUWL output water have provided indirect evidence for antiretraction valve failure [3,29,31]. A study in Italy of 54 DCUs, consisting of a wide range of models by several different manufacturers, documented malfunction of antiretraction devices in $74 \%$ of cases [48]. Therefore, retraction or backsiphonage of oral fluids into DUWLs during dental instrument use can expand the range of microorganisms present both in DUWL biofilm and output water. This increases the possibility of transmission of more pathogenic humanderived microorganisms such as Staphylococcus aureus to staff and patients. S. aureus is carried in the nasal cavity of a significant proportion of humans and is readily trafficked from the nasal cavity to the oral cavity. One recent study reported the isolation of $S$. aureus from saliva in $46 \%$ of patients sampled and from $34 \%$ of plaque samples tested [51]. S. aureus is a major human pathogen with the potential to express a considerable arsenal of chromosomal, plasmid and bacteriophage-encoded virulence and immune evasion factors and antimicrobial agent resistance determinants [52-55]. Another recent study reported the detection of HCV RNA in DUWLs from DCUs where the antiretraction valves had been deactivated and from DCUs without antiretraction valves following treatment of known HCV-infected patients [56]. The Centers for Disease Control and Prevention (CDC) guidelines for infection control in dentistry advocate that dental handpieces should be flushed for 20-30 s to elute water and air after completion of individual patient treatments in order to minimize the potential impact of the retraction of oral fluids into DUWLs [57]. Dental instruments equipped with antiretraction devices should be subject to routine efficacy testing and preventive maintenance to minimize instances of antiretraction valve failure [5].

\section{Contamination of reservoir bottles}

Some DCUs use independent water reservoir bottles to provide water to the DUWLs. These bottles are manually filled with water (mains water, distilled water or sterile water) but can 
easily become contaminated with skin bacteria such as Staphylococcus epidermidis and S. aureus, the latter a common human pathogen, thus introducing additional human microorganisms into DUWLs [58]. To avoid this problem, DCU reservoir bottles should be handled with care to minimize contamination with skin squames and should be cleaned and disinfected regularly. Preferably, reservoir bottles should be regularly sterilized in an autoclave after thorough cleaning before refilling and re-use [59].

\section{Microorganisms found in DUWL output water \\ Environmental microorganisms}

Gram-negative aerobic heterotrophic environmental species of low pathogenicity comprise the majority of microbial species found in DUWL output water [25,27,29,60-63]. The types and range of environmental bacterial species present may vary from one geographic area to the next. Some of these bacterial species may be of concern in the treatment of immunocompromised patients. The environmental bacteria are of concern as they predominantly initiate biofilm formation and are often responsible for the excreted protective polymeric matrix that affords protection to more pathogenic species. They may also produce enzymes (e.g., catalase) or other substances that reduce the efficacy of disinfectants and over time, these populations may become selectively enriched [62] .

Fungi, yeasts, protozoa and amoebae can also be present in DUWL output water, although contamination by these microorganisms is less prevalent and the organisms are present at lower densities than bacteria [14,64-67]. However, protozoa and amoebae can host legionellae and may predispose DUWL output water to contamination with Legionella bacteria [3]. Known human bacterial pathogens recovered from DUWL output water include Pseudomonas species, particularly Pseudomonas aeruginosa, Legionella species, particularly L. pneumophila and nontuberculosis mycobacterial species $[21,40,42,68-70]$.

\section{Human-derived microorganisms}

As outlined in the previous sections, oral and skin bacteria have been reported in contaminated DUWL output water, most likely owing to retraction of oral fluids into DUWLs following DCU instrument use in the oral cavity and from contamination of reservoir bottles or bulk storage containers with skin squames when bottles are being handled or filled.

\section{Evidence for disease associated with contaminated DUWLs Microorganisms}

In 1987, a study by Martin described an association between $P$. aeruginosa isolates recovered from oral abscesses in two cancer patients and their recent exposure to contaminated DUWL water during dental treatment from separate DCUs in the same dental clinic [20]. For each patient, pairs of $P$. aeruginosa isolates, one isolate recovered from the patient's abscess and one recovered from DUWL output water from the DCU used to treat the patient, had the same pyocin type. Different pyocin types were recovered from each of the two patients with abscesses. These findings have been cited repeatedly as providing convincing evidence for disease transmission from contaminated DUWL output water. However, $P$. aeruginosa only has a limited number of pyocin types and thus discriminatory power is somewhat restricted. In this regard, the study by Martin does not provide definitive proof that the patient isolates belonged to the same strain as the isolates recovered from DUWLs, although it is possible [20].

Legionella spp. (L. pneumophila and approximately 40 other spp.) are frequently present in man-made water distribution systems and can cause Legionnaire's disease (pneumonia resulting from inhalation) or Pontiac fever (a flu-like illness without pneumonia). Legionellae are intracellular parasites of a range of amoebae and protozoa that live in soil and water, often in conjunction with biofilms. Many reports have identified Legionella bacteria in DUWL output water [42,63,65,70-72]. Interestingly, Barbeau and Buhler found that the density of free-living amoeba was up to 300-times higher in DUWL output water samples compared with tap water within the same clinical environment [73]. However, to date there is no unequivocal published data documenting acquisition of Legionnaire's disease following exposure to contaminated DUWL output water. One study concluded that the death of a dentist from Legionnaire's disease was likely caused by occupational exposure to Legionella bacteria-contaminated aerosols [42]. High levels of Legionella bacteria (>10,000 organisms per $\mathrm{ml}$ ) were detected in the DUWL output water in the dental surgery, whereas low levels ( $<100$ organisms per $\mathrm{ml}$ ) were detected from the dentist's domestic water supply. However, it was not possible to definitively prove that the cause of death was due to Legionella bacteria contracted from contaminated DUWL output water. A number of studies have indicated that occupational 
exposure of dental healthcare staff to aerosols of waterborne bacteria generated by dental instruments attached to DUWLs may lead to a higher prevalence of antibodies to Legionella [40,74]. Fotos et al. reported that $23 \%$ of dental healthcare staff that worked in practice for more than 2 years were serum anti-L. pneumophilia IgG antibody-positive and $19 \%$ were serum anti-L. pneumophilia IgM antibody-positive. By contrast, only $8 \%$ of subjects tested who had no clinical contact were anti-L. pneumophilia IgG antibody-positive [40].

A recent case report highlighted the risks that may be associated with amoebae in DUWL output water [75]. A patient with contact lenses received a stream of water from a dental handpiece into the right eye during dental treatment. The patient subsequently experienced pain in the eye, and consulted several ophthalmologists, who identified abrasive lesions of the cornea and inflammation. Despite antibacterial and antiinflammatory therapy, the patient's eye condition worsened. A microbiological examination nearly 2 months later identified amoebae in corneal samples and a lawsuit against the dental practitioner was initiated, which was unsuccessful on the grounds of failure to definitively establish a causal relationship with the dental treatment and the presence of amoebae in the patient's eye. The patient used to routinely rinse her contact lenses using tap water and this may have been the source of the amoebae. Nevertheless, this case highlights that high densities of amoebae in DUWL output water may present a risk if a patient with preexisting corneal lesions is splashed. This case reinforces the importance of having patients wear safety glasses during dental treatments, and more importantly, of ensuring good quality DUWL output water.

Although only a few cases of infection associated with contaminated DUWL output water have been reported [20,42], it is conceivable that such infections have not been identified because of the failure to associate infections with exposure to DUWL output water and associated aerosols [63]. Sporadic infections not requiring hospitalization are also less likely to be investigated. Furthermore, it would be extremely difficult to trace the origin of an infection contracted from contaminated DUWL output water where the clinical manifestations develop a number of weeks after exposure.

\section{Endotoxins}

Dental unit waterline output water can be a major source of bacterial endotoxins (lipopolysaccharide) released from the cell walls of
Gram-negative bacteria. Levels up to 100,000 endotoxin units (EU) per $\mathrm{ml}$ have been reported in DUWL output water $[28,63,76]$. Significant endotoxin levels ( $\left.>100 \mathrm{EU} \mathrm{m}^{-3}\right)$ have also been reported in aerosols generated from contaminated DUWL output water by dental instruments [76]. The maximum level of endotoxin permissible in sterile water for irrigation in the USA is $0.25 \mathrm{EU}$ per ml. Inhaled endotoxin can exacerbate airflow obstruction and airway inflammation in individuals with allergic asthma and asthma severity is directly correlated with concentration of endotoxin [77]. In medical devices that are prone to biofilm growth and endotoxin accumulation such as humidifiers, a hypersensitivity pneumonitis due to endotoxin exposure is well recognized [63]. A study by Putnins et al. indicated that endotoxin present in DUWL output water might stimulate the release of proinflammatory cytokines in gingival tissue during oral surgery and adversely affect healing [28]. Only sterile solutions should be used for irrigation during oral surgery procedures. In addition, data from a single, large, practicebased cross-sectional study reported a temporal association between occupational exposure to contaminated DUWL output water with aerobic bacterial counts of $>200 \mathrm{CFU} / \mathrm{ml}$ at $37^{\circ} \mathrm{C}$ and development of asthma in a subgroup of dentists in whom asthma arose following the commencement of dental training [78].

\section{Dental unit supply \& output water quality DCU supply water}

The majority of DCUs in countries within the European Union are supplied with potable quality mains water [31]. The water supply in some DCUs is provided from water reservoir bottles integrated in the main body of the DCU. These are filled with water from a variety of sources as required, including mains water, distilled water or sterile water. However, in dental hospitals and large clinics equipped with many DCUs, the water provided to DCUs is frequently supplied from water storage tanks supplied with mains water $[3,5]$. It follows that the more microorganisms present in DCU supply water, the more readily biofilm will form in DUWLs.

The current potable water standard for the European Union and the USA stipulate the absence of fecal coliforms but do not specify an upper limit for aerobic heterotrophic bacteria, the bacterial species most frequently isolated from contaminated DUWL output water $[79,201]$. By contrast, potable water sold in bottles or containers in the European Union should 
not exceed $100 \mathrm{CFU} / \mathrm{ml}$ of aerobic heterotrophic bacteria. DCU supply water from storage tanks filled from a potable supply tend to have higher densities of bacteria than potable quality water, most likely due to biofilm formation on the inner surfaces of the tanks and/or owing to the presence of sediment [80]. Furthermore, the condition of the mains water distribution pipe work and water storage tanks, together with the presence of sediment, sludge or corrosion deposits throughout the water distribution system can also contribute significantly to a reduction in the quality of water supplied to DCUs. The quality of water supplied to DCUs from reservoir bottles is influenced by several factors, including the quality of the water itself and the presence of biofilms on the internal surfaces of reservoir bottles. Furthermore, if reservoir bottles are supplied with distilled water, the microbiological quality will be influenced by the condition and cleanliness of the distilled water storage containers, on how long and under what conditions the water is stored prior to use, and on the condition and cleanliness of the distillation unit. Furthermore, distilled water is often purchased from third party suppliers and is often stored in plastic containers, frequently for extended periods. In other cases, water from a distillation unit is stored in plastic containers that are reused repeatedly. The growth of biofilm on the internal surfaces of these containers can cause a rapid deterioration in the microbiological quality of the water used to fill reservoir bottles. Finally, contamination of water stored in containers, (including distilled and sterile water) with skin bacteria can add to the burden of bacteria and reduce the quality of water supplied to DCUs.

Temperature and the presence of suspended material, particulate matter, organic material and suspended and dissolved inorganic compounds in DCU supply water can directly affect the development and proliferation of biofilms within DUWLs [3,5]. Aerobic heterotrophic bacteria can convert organic material in supply water into biomass locally, thus contributing to the growth of biofilm [81]. The level of inorganic nutrients present in supply water can also influence biofilm growth within DUWLs. The chemical and microbial content of mains water supplied to DCUs will vary according to geographic area and the extent of water treatment by municipal authorities. Hard water areas can also be a source of additional problems for DCUs and DUWLs. Hard water is water with a high dissolved mineral content and usually contains high concentrations of $\mathrm{Ca}^{2+}$ and $\mathrm{Mg}^{2+}$ ions.
These dissolved minerals and ions enter a water supply by leaching from naturally occurring minerals such as calcite, gypsum and dolomite and form insoluble deposits, composed mainly of calcium carbonate, magnesium hydroxide and calcium sulphate, on the internal surfaces of water network pipes and tanks. The extent of water hardness depends on the levels of dissolved magnesium and calcium minerals. If hard water (e.g., 200 ppm hardness minerals) is supplied to DCUs, insoluble mineral deposits precipitate within DUWLs and associated valves, increasing the surface area within DUWLs, thus allowing more biofilm to form [3,5]. It may be necessary to implement pretreatment of DCU supply water in situations where the quality of supply water is poor or varies considerably. This is discussed in more detail later.

\section{DUWL output water}

Heavily contaminated DUWL output water, containing up to $10^{8}$ bacteria per $\mathrm{ml}$, is not consistent with best practice in infection prevention and control $[3,5,63,78,82]$. However, there are no standards or legislation specifically pertaining to the microbiological quality of DUWL output water and, until recently, DCU manufacturers have only provided limited direction in this regard, despite the fact that DCUs are classified as medical devices $[5,6]$. The fundamental underlying rationale for the lack of specific DUWL quality standards stems from the reality that the purpose of this water is to cool and irrigate dental instruments and tooth surfaces rather than for human consumption. Nonetheless, DUWL output water is usually swallowed in small amounts during treatment and aerosols generated by dental instrument use are inhaled. Therefore, the microbiological quality of DUWL output water should be such that potential cross-infection risks and other health risks are minimized. This raises the question, should DUWL output water be of potable quality? However, the potable water standards for the European Union and the USA do not specify an upper limit for aerobic heterotrophic bacteria, the most frequently encountered microorganisms found in DUWL output water [79,201]. In an attempt to address this issue, the American Dental Association (ADA) Council on Scientific Affairs set a goal for the year 2000 that water used for dental treatment should contain $\leq 200 \mathrm{CFU} / \mathrm{ml}$ of aerobic heterotrophic bacteria [83]. Many experts in the field have endorsed this recommendation [84], but in fact it has not been widely achieved $[5,63]$. The current CDC 
guidelines for infection control in dental healthcare settings recommend that DUWL output water should not exceed $500 \mathrm{CFU} / \mathrm{ml}$ of aerobic heterotrophic bacteria [57]. In 2004, the ADA revised their recommendation on DUWL output water quality to be consistent with the CDC guideline [202].

\section{Controlling microbial contamination of DUWL output water}

A variety of approaches to reducing the microbial density in DUWL output water have been tested over the last 20 years or more (TABLE 1$)$. These include the disinfection of DUWLs with chemical and other nonchemical-based approaches. Overall, chemical-based approaches have been the most successful.

\section{Nonchemical approaches}

Flushing DUWLs with water has widely been used to reduce the density of microorganisms in DUWL output water $[3,85]$. This approach does reduce the levels of microorganisms in DUWL output water to some extent, but it is not effective as a means of ensuring good quality DUWL output water because it has no impact on biofilms present in DUWLs. Another approach to improve the quality of DUWL output water involves the use of sterile water, distilled water or deionized water in DCU reservoir bottles (TABlE 1). This approach is ineffectual if biofilms are already resident in DUWLs as the biofilms will continue to shed planktonic organisms and pieces of biofilm into the DUWL output water. Draining DUWLs after use and drying them with pressurized air has also been attempted as a means of improving the quality of DUWL output water [86]. However, following reconnection of the DUWLs to the water supply, the number of viable microorganisms in DUWL output water was not reduced significantly probably because biofilm matrix, being highly hydrated, can withstand desiccation for extended periods and thus protects resident microorganisms. Fitting microbial filters to DUWLs near the dental instrument attachment sites or to the DCU supply have also been used to improve the quality of DUWL output water [87-89]. This approach can be very effective but disadvantages include frequent clogging of filters and therefore the requirement to change filters often, resulting in increased maintenance and running costs. Furthermore, filters have no impact on biofilms resident in DUWLs. A number of studies investigated the effect of DUWL composition on biofilm formation and reducing microbial contamination of DUWL output water [3,5]. One such study reported that some materials, such as polyvinylidene fluoride, were more effective at resisting biofilm formation and in reducing the level of contamination in DUWL output water than conventional DUWL tubing made of polyurethane [90]. However, despite this reduction, levels of bacteria in DUWL output water remained unacceptably high.

\section{Application of chemical disinfectants}

Many studies have shown that the most effective way of ensuring good quality DUWL output water is regular treatment/disinfection of DUWLs with a chemical disinfectant, biocide or cleaning agent that efficiently removes biofilm from DUWLs [5,29-31,61,62,91]. Because biofilm regrowth in DUWLs occurs shortly following disinfection/cleaning due to recolonization by microorganisms in supply water and/or from fluids retracted back into DUWLs from dental instruments, DUWLs need to be treated regularly to control biofilm [3,22,29,30,61,62,92]. Numerous studies have demonstrated the effectiveness of a broad range of DUWL treatment products that eradicate biofilm and reduce bacterial levels in DUWL output water to potable water quality or better (TaвLE 1). However, a significant number of these studies were undertaken in vitro and relatively few investigated the efficacy of DUWL treatment products in DCUs [29,30,61,62,80,93-95]. Moreover, only a small proportion of studies investigated the long-term efficacy of DUWL treatment agents in DCUs in the clinical setting $[61,62,80]$.

\section{DUWL biofilm treatment agents}

Dental unit waterline treatment agents can be divided into periodic or intermittent (e.g., used once weekly) DUWL treatment agents and agents for continuous or residual DUWL treatment. Table 1 lists the range of DUWL treatment agents that have been used to control biofilm in DUWLs. Laboratory and field-testing studies have shown that their efficacy varies widely. Treatment agents that remove DUWL biofilm provide the best approach for improving the quality of DUWL output water [3]. Walker et al. appraised a range of chemical DUWL treatment agents and reported that only some have been shown to successfully remove biofilm and consistently reduce the microbial load of DUWL output water to $<200 \mathrm{CFU} / \mathrm{ml}$ [96]. The more common DUWL treatment agents are based on a range of chemical compounds including hydrogen peroxide, hydrogen peroxide 


\section{Review O'Donnell, Boyle, Russell \& Coleman}

Table 1. Nonchemical approaches and the principal chemical agents that have been used to improve the microbiological quality of dental unit waterlines output watert.

\section{Approach}

\section{Nonchemical methods}

Antiretraction valves integrated into DCU-supplied instruments Use of microbial filters at the ends of DUWLs near the instrument attachment sites or on DCU supply water lines

Draining or drying of DUWLS

Use of distilled water, deionized water, sterile water or pasteurized DUWL supply water provided from reservoir bottles

Flushing of DUWLs with fresh water

\section{Chemical agent ${ }^{*}$ tested in DCUs}

Chlorhexidine gluconate, chlorhexidine gluconate and alcohol (I)

Activated chlorine dioxide (I), chlorine dioxide and sodium phosphate mouth rinse (R) Glutaraldehyde (I), glutaraldehyde and quaternary ammonium salts (I) Sodium hypochlorite (I) (R)

Sodium hypochlorite and citric acid (I)

Hydrogen peroxide (I) (R) Hydrogen peroxide and silver (I) Alkaline peroxide (I)

Electrochemically activated solutions $(R)$

Peracetic acid (I)

Povidone-iodine (I)

Sodium fluoride (I)

Sodium perborate (I)

EDTA (I)

Citric acid and sodium- $p$-toluolsulfonechloramide and sodium $\operatorname{EDTA}(R)$

Sodium- $p$-toluol-sulfonechloramide Effective at minimizing microbial density in DUWL output water $\operatorname{EDTA}(\mathrm{R})$

p-hydroxybenzoeicacidester, polyaminoprophylbiguanid,

1,2-prophyenglycol

${ }^{\dagger}$ For the purpose of conciseness, not every published study with nonchemical approaches or with individual chemical treatment agents is included.

*Only agents actively tested in DCUs as opposed to those tested with model systems, including DUWL tubing taken from working DCUs, have been included in this table.

DCU: Dental chair unit; DUWL: Dental unit waterlines; I: Intermittent treatment; R: Residual or continuous treatment.
Ref.

Antiretraction valves fail frequently resulting in retraction of oral fluids into

$[48,52]$

Can be effective in reducing microbial density in DUWL output water but

has no effect on biofilm resident in DUWLs. Filters can be prone to

clogging and have to be replaced regularly. Few remove bacterial

endotoxin from water

Has little effect on improving DUWL output water quality as biofilm

Has little effect on improving DUWL output water quality if biofilm is

already resident in DUWLs. New DCUs may come with biofilms formed

during factory quality testing

Results in reducing the microbial density in DUWL output water, but not to acceptable levels. Has no effect on DUWL biofilm

$[3,22,85,113,114]$

Variable removal of DUWL biofilm. Effective at minimizing contamination

$[64,112,115]$

of DUWL output water

Effective at minimizing contamination of DUWL output water

$[35,59,116,117]$

Variable efficacy at eliminating biofilm and reducing microbial density in

$[118,119]$

Variable efficacy at eliminating biofilm and reducing microbial density in DUWL output water

$[120-122]$

Effective at minimizing microbial density in DUWL output water

[95]

Effective at eliminating biofilm and minimizing microbial density in DUWL output water. Reports of clogging of DUWLs following repeated use of

$[29,35,56,57,95,109,112$ alkaline peroxide

Very effective at eliminating biofilm and minimizing microbial density in DUWL output water. $\mathrm{pH}$ range of products is 2.0-7.4. $\mathrm{pH}$-neutral products are best as they do not show adverse effects on DCU components.

Ecasol shown to lack cytotoxicity for human keratinocytes and reconstituted human oral epithelium

Not effective at minimizing microbial density in DUWL output water

$[80,97-100]$

Effective at minimizing microbial density in DUWL output water but only partial elimination of biofilm

Variable efficacy at minimizing microbial density in DUWL output water biofilm removal

Two-phase treatment product. Effective at minimizing microbial density in DUWL output water
Effective at minimizing microbial density in DUWL output water 
combined with silver ions, sodium hypochlorite, chlorine dioxide, chlorhexidine, peracetic acid and citric acid. Other products such as electrochemically-activated solutions have also shown good potential for microbial control of DUWL output water [80,97-100]. In a large study in which a range of DUWL treatment agents were tested for efficacy in DCUs ( $\mathrm{n}=134)$ in general practice in several European countries, some of the most effective treatment agents evaluated contained hydrogen peroxide or a combination of hydrogen peroxide and silver ions, which efficiently remove DUWL biofilm [96]. Overall, continuously applied products performed better than those applied periodically.

\section{Unfavorable effects of DUWL biofilm treatment agents}

The use of chemical agents to control biofilm formation in DUWLs has potential for adverse effects on DCU components and instruments, on patient oral tissues and on dental restorative materials. This is particularly pertinent for residual treatment agents that are present in DUWL output water, which enter the patient's oral cavity and may also be swallowed or inhaled from aerosols generated by dental instruments. Only a few studies of the long-term effectiveness of DUWL treatment agents have been reported to date and thus there is a dearth of independent information on potential adverse effects. In the case of residual DUWL treatment agents, very few independent studies have investigated potential interactions of residual agents and their by-products on oral tissues and teeth. Furthermore, many DUWL treatment agents have not been tested or endorsed by DCU manufacturers, but have been developed independently by other manufacturers [5]. In this regard there is considerable potential for incompatibility of DUWL treatment agents with components of the DUWL network as well as with dental instruments supplied by DUWLs [5].

A study of DUWL disinfection using an alkaline hydrogen peroxide agent for periodic use reported obstruction of DUWLs by disinfectant deposits in three out of six DCUs tested [29]. The problem became evident after 4 weeks of onceweekly treatment in the three DCUs, and in one of these, after 14 weeks the DUWL supplying the air/water syringe DUWL became completely blocked. The presence of disinfectant deposits in DUWLs caused the output water from these DCUs to remain alkaline for extended periods, despite extensive daily flushing with fresh mains water [3,29], highlighting a potential risk to patients from exposure to disinfectant residue in DUWL output water. A separate study on the long-term effectiveness of the hydrogen peroxide-and silver-ion-containing, intermittent-use DUWL disinfectant Planosil reported adverse effects on several DCU components, including corrosion of aluminum components and valve damage caused by hydrogen peroxide, after prolonged use [62]. The study reported that the problems identified were resolved in collaboration with the DCU manufacturer by replacing the affected DCU components with parts that were resistant to corrosion by hydrogen peroxide [62]. This report highlighted both the importance of examining the long-term effects of prolonged usage of DUWL treatment agents on DCUs and the role of DCU manufacturers in ongoing research and development.

Most DCUs are provided with an integrated suction system to remove surplus fluids and debris from the oral cavity during dental treatment and to minimize aerosol release during the use of dental handpieces and ultrasonic scalers [101]. Fluids removed from the oral cavity by DCU suction hoses are eventually released into the wastewater stream after particle and dental amalgam removal and disinfection. Amalgam separators form part of the DCU suction system and trap amalgam particles removed from the oral cavity by DCU suction hoses as amalgam contains mercury [3]. The effectiveness of amalgam separators varies and consequently the mercury concentration in DCU wastewater [102]. Stone $e t$ al. reported that residual treatment of DUWLs with low concentrations of iodine to control biofilm formation might cause the release of toxic dissolved mercury into the environment from DCU wastewater [103]. However, other authors disputed these findings and argued that chloramine (a chemical disinfectant) used to disinfect municipal water was more likely to have been responsible for the increase in mercury levels [104]. Two other laboratory studies reported that a number of chemical agents used to treat DCU wastewater lines also cause the release of mercury from dental amalgam and concluded that agents containing high levels of chlorine were the most problematic in this regard [105,106]. Thus, chlorine-containing DUWL treatment agents may also mobilize mercury from amalgam in DCU wastewater into the environment.

A number of studies reported that some DUWL treatment products containing citric acid, sodium hypochlorite and chlorhexidine gluconate combined with $12 \%$ ethyl alcohol, may adversely affect bonding of composite material to dentine and enamel $[107,108]$. 
Very few independent studies have actually demonstrated the safety of DUWL treatment agents that come in direct contact with the oral cavities of patients [3,5]. This applies mainly to residual agents as periodic DUWL treatment agents should be flushed from DUWLs with fresh water following DUWL treatment. One recent study investigated the biosafety of Trustwater ${ }^{\mathrm{TM}}$ Ecasol ${ }^{\mathrm{TM}}$, an effective residual DUWL treatment agent consisting predominantly of metastable hypochlorous acid generated by electrochemical activation of a dilute salt solution [100]. Levels of Trustwater Ecasol used for DUWL treatment ranged from 1-2.5 ppm. This study used two in vitro model systems to investigate potential cytotoxic effects of Ecasol. TR146 human keratinocyte monolayers and reconstituted human oral epithelium (RHE tissue, a 3D tissue culture model comprised of TR146 cells grown on filters), were treated with Ecasol (2.5-100 ppm) for $1 \mathrm{~h}$ periods following thorough washing with phosphate buffered saline to remove culture medium. Similar experiments were undertaken with Ecasol that was pretreated with $1-2 \mu \mathrm{g} / \mathrm{ml}$ bovine serum albumin corresponding to the protein concentration in human saliva [100]. Cytotoxic effects on TR146 monolayers were determined using the alamarBlue ${ }^{\circledR}$ assay (assesses cell viability) and the Trypan Blue dye exclusion assay (assesses cell membrane integrity). Cytotoxic effects on RHE tissues were investigated using histopathology and the alamarBlue assay. Ecasol concentrations $>5.0 \mathrm{ppm}$ were found to cause significant $(\mathrm{p}<0.001)$ cytotoxicity to keratinocyte monolayers following a $1 \mathrm{~h}$ exposure, an effect that was completely abolished by pretreatment of Ecasol with bovine albumin. No cytotoxicity was seen in the more complex RHE tissue at any of the Ecasol concentrations tested [100]. These findings showed that Ecasol present as a residual disinfectant in DUWL output water is very unlikely to have adverse effects on human oral tissues at levels effective in maintaining good quality DUWL output water.

\section{Pretreatment of DCU supply water}

Some consideration should be given to pretreating DCU supply water for DCUs, particularly DCUs supplied with tank water such as in dental hospitals and dental clinics equipped with large numbers of DCUs [5]. The quality of DUWL output water is directly influenced by the quality of the supply water. The aim of pretreatment should be to utilize a simple integrated system suited to the performance requirements that will provide consistent quality water for DUWLs, regardless of fluctuations in the supply water quality (i.e., mains supply or tank supply). Final treatment or disinfection of a consistent quality supply then becomes much simpler. A wide range of commercially available filters can be utilized for dealing with specific problematic aspects of DCU supply water quality including sediment filters (remove suspended solid contaminants), activated carbon filters (remove organic contaminants), water softening units for use in hard water areas and Kinetic Degradation Fluxion (KDF) filters that remove some dissolved metals $[3,5,80]$. Sediment filters should be fitted in-line with the incoming water supply before any other water filter or unit. Sediment filters extend the working life of other types of filter by removing coarse contaminants and sediment particles that otherwise could reduce the efficacy of filters fitted downstream such as carbon filters and water softeners. Many of the filter types mentioned above have integrated backwash facilities that can be programmed to operate when the filters are not in use $[3,5,80]$. Backwashing removes contaminants, increases filter efficiency and allows regeneration of ion exchange resins used in water softening units increasing the lifespan of the resin. Despite the presence of a backwashing facility, all water filter units require periodic maintenance and disinfection as biofilm can form within them after extended use, particularly in water softening resin and carbon filter beds, which can add significant microbial densities to water entering DUWLs downstream of filtration units.

\section{Factors contributing to inadequate DUWL disinfection}

While few studies have investigated the longterm effectiveness of DUWL cleaning/disinfection agents, even fewer studies have investigated factors that contribute to inadequate DUWL disinfection with specific treatment agents or factors that contribute to DUWL disinfection failure. In 2007, a study by O'Donnell et al. investigated the long-term (21 months) effectiveness of the hydrogen peroxide and silver ion-containing DUWL disinfectant Planosil to maintain the quality of DUWL output water below the ADA recommended standard of $\leq 200 \mathrm{CFU} / \mathrm{ml}$ of aerobic heterotrophic bacteria using once weekly disinfection in ten Planmeca Prostyle Compact DCUs [62]. In the first 9 month part of the study a high incidence $(9.3 \%)$ of intermittent DUWL 
disinfection failure occurred. On investigation, several contributory factors were identified, the first of which was low compressed air pressure that resulted in inadequate distribution of disinfectant throughout the DUWL network. Other factors identified included operator failure to include one of the three-in-one air/ water syringes in the disinfection cycle and corrosion of DCU components by the DUWL disinfectant. Having identified these problems, corrective measures were put in place to prevent reoccurrence of intermittent DUWL disinfection failure due to these causes, including DCU component changes and ensuring strict compliance with the DUWL cleaning protocol. In the second part of the study a significantly increased prevalence of strongly catalase-positive Novosphingobium and Sphingomonas bacterial species $(\mathrm{p}<0.0001)$ occurred in four out of ten DCUs included in the study and resulted in rapid deterioration in DUWL output water quality by the fourth day postdisinfection [62] Catalase is an enzyme commonly produced by bacteria where it functions to catalyze the decomposition of hydrogen peroxide. The increased prevalence of these strongly catalasepositive environmental bacterial species in DUWL output water following extended use of Planosil, one of the active ingredients of which is hydrogen peroxide, indicated selective pressure for retention of these species, which would have a survival advantage in DUWLs exposed regularly to hydrogen peroxide. Similar findings were reported in a separate study on DUWL treatment with Oxygenal $6^{\circledR}$, another hydrogen peroxide- and silver ion-containing DUWL treatment agent, where the prevalence of Sphingomonas paucimobilis in DUWL output water increased from $10 \%$ pre-disinfection to $80 \%$ postdisinfection [109]. The study by O'Donnell et al. concluded that over the long term, a variety of features can each be a factor in DUWL disinfection failure including inadequate compliance with DUWL disinfection protocols, adverse effects of disinfectants on DCU components and selection of intrinsically disinfectant-tolerant bacteria [62]. The long-term problems associated with DUWL disinfection identified in the study by O'Donnell et al. [62] probably occur with other brands and models of DCU and with other DUWL treatment agents and highlight the importance of long-term compatibility testing of DUWL treatment agents with DCUs, and the development of DUWL cleaning systems that are automated and require minimal human input.

\section{DCUs with integrated DUWL disinfection units}

Over the last 10 years the Finnish DCU manufacturer Planmeca Oy (Helsinki, Finland), in collaboration with applied microbiologists have developed the next generation of DCUs containing microprocessor-controlled, integrated and semiautomated DUWL disinfection units that facilitate DUWL disinfection $[5,29,61,62]$. These include the Waterline Cleaning System (WCS ${ }^{\mathrm{TM}}$ ) and the Water Management System (WMS ${ }^{\mathrm{TM}}$ ). The WCS is a semiautomated DUWL cleaning system used in DCUs supplied with mains water in which all DUWLs are supplied with disinfectant from a central reservoir when the DUWL disinfection function is activated. Following overnight disinfection, DUWLs are automatically purged of disinfectant and flushed extensively with fresh mains water. During the disinfection cycle, all other DCU functions are inactivated until the disinfection cycle is completed [29,62]. The WMS is an integrated DUWL cleaning system that requires minimal effort on the part of the user, is more advanced and automated than the WCS [6]. A number of studies have demonstrated the long-term effectiveness of both the WCS and the WMS using the hydrogen peroxide- and silver ion-containing disinfectant Planosil to maintain the quality of DUWL output water below the ADA standard of $<200 \mathrm{CFU} / \mathrm{ml}$ of aerobic heterotrophic bacteria following once weekly disinfection [29,61,62] . As mentioned earlier, independent long-term studies with the WCS in Planmeca Prostyle Compact DCUs identified several factors that contributed to episodes of DUWL disinfection failure, including human error, disinfectant corrosion of DCU components and selection of disinfectant-tolerant bacterial species, all of these problems were solved by ensuring strict operator compliance with the disinfection protocol, design changes to DCU components and reformulation of the DUWL disinfectant used [62]. The development and ongoing improvement of integrated DUWL cleaning systems by DCU manufacturers is a very welcome development as it provides an easy-to-use and validated process for dental staff to consistently maintain good-quality DUWL output water in the long term.

\section{Centralized \& automated control of DUWL output water quality}

For most DCUs, controlling biofilm in DUWLs by periodic or residual chemical agent treatment is usually undertaken separately for each 
individual DCU. In dental hospitals and other dental clinics equipped with large numbers of DCUs, ensuring consistent good quality DUWL output water from every DCU can be demanding, even if they have integrated DUWL cleaning systems. Ensuring good quality DUWL output water from every DCU requires consistent strict adherence to DUWL cleaning/disinfection protocols using effective DUWL treatment agents. Furthermore, the quality of DCU supply water and contamination controls, and the cleanliness and state of repair of the water distribution network (i.e., pipe work and tanks) need to be monitored regularly. In busy dental hospitals and clinics this can make significant demands on dental and maintenance staff and resources, but is vital.

In 2009, a study by O'Donnell et al. reported the development of a fully automated, centralized water treatment system at the Dublin Dental University Hospital (Dublin, Ireland) to automatically manage the quality of DCU supply and DUWL output water throughout the hospital [80]. The centralized system consists of two interlinked elements, the first of which involves subjecting chlorinated mains water to automatic processing by particle filtration, followed by activated carbon filtration, followed by KDF filtration and finally by passage through an ion exchange water softening unit. Processed water is then stored in a water storage tank providing water to the hospital's 103 DCUs by means of a recirculating ring main [80]. Throughout the study, extensive testing showed that the system maintained the chemical quality of DCU supply water better than potable water standards $[79,201,80]$. The second element of the system consists of automated treatment of the processed water with Trustwater Ecasol at $2.5 \mathrm{ppm} / \mathrm{ml}$. Ecasol is a neutral electrochemically activated solution consisting predominantly of metastable hypochlorous acid, which is microbiocidal, sporocidal and capable of penetrating biofilms $[3,80,100]$. Ecasol is generated in situ from supply water, a small amount of $\mathrm{NaCl}$ and electricity, using a Trustwater ECA generator, (Trustwater, Clonmel, Ireland). The level of Ecasol in the water network is maintained constant by a series of in-line probes and equipment that monitor free available chlorine. The study monitored the performance of the centralized system by determining the microbiological quality of processed and Ecasol-treated DCU supply water and DUWL output water from ten sentinel DCUs weekly for a 100 -week period. DUWLs were tested for the presence of biofilm by electron microscopy. Over the 100 -week study period, the DCU supply water and DUWL output water aerobic heterotrophic bacterial counts averaged $<1$ and $18.1 \mathrm{CFU} / \mathrm{ml}$, respectively, from the ten DCUs, compared with $88 \mathrm{CFU} / \mathrm{ml}$ for unprocessed mains water. This correlated with the absence of biofilm in DUWLs. No adverse effects due to Ecasol treatment of supply water were observed for DUWLs or DCU instruments during the study period [80]. In a followup study of the centralized water treatment system reported by Boyle et al. undertaken over a 60-week period with ten DCUs, tested weekly, the average density of aerobic heterotrophic bacteria in Ecasol-treated (2.5 ppm) DCU supply water was $<1 \mathrm{CFU} / \mathrm{ml}$ and in DUWL output water was $6.5 \mathrm{CFU} / \mathrm{ml}$ [100]. Again no adverse effects due to Ecasol treatment of supply water were observed for DUWLs or DCU instruments during the study period. The results of these two studies demonstrated unequivocally that the centralized and automated water treatment and biofilm management system consistently maintain DUWL output water at better than potable quality simultaneously in a large number of DCUs over the long term. As described in the previous section, cytotoxicity studies with cultured human keratinocytes and RHE tissue revealed that Ecasol, at the levels used for DUWL treatment (2.5 ppm), is very unlikely to have adverse effects on human oral tissues as the presence of saliva ensures the neutralization of Ecasol [100].

The automated system described by O'Donnell et al. requires minimal human intervention, although consumable reagents for specific components have to be replenished monthly $(<30 \mathrm{~min}$ to implement) and 6-monthly planned preventive maintenance on equipment [80]. Water softening, carbon filter and KDF filter media only have to be replaced on a 3-5-year cycle. The centralized system provides an environmentally friendly solution to DCU water management. Overall, operation of the centralized system yielded significant savings in running cost, disinfection and flushing time and equipment downtime, compared with individual disinfection of DUWLs in DCUs.

\section{Conclusion}

Microbial biofilm contamination of DUWLs and consequent poor-quality DUWL output water has been recognized as an important problem in dentistry for nearly 50 years and is still a problem today. It is essential that dental staff strive to maintain output water quality from their DCUs at a level consistent with the current ADA recommendation of $\leq 500 \mathrm{CFU} / \mathrm{ml}$ of aerobic heterotrophic bacteria or better because of 
the increasing number of immunocompromised and other vulnerable patients seeking dental treatment. However, attaining this level of output water quality from DUWLs consistently has been difficult to achieve in practice for several reasons including the absence of specific quality standards and because DCU manufacturers have been slow to tackle the problem by redesigining DCUs and by the provision of precise guidance on DUWL disinfection. In recent years there has been constructive progress in this area with the development of validated, integrated and automated DUWL disinfection systems by some DCU manufacturers for use with specified chemical DUWL treatment agents that are consistently effective in the long term and compatible with their DCUs. Long-term studies with these systems have demonstrated that the problem of DUWL biofilm can be resolved effectively in dental clinics. It is clear that there is not one solution to improve DUWL output water quality for every dental clinic as clinics may be equipped with one or many DCUs, often of a wide variety of ages, model types and manufacturer. DCUs in clinics may also be supplied directly by mains water or indirectly by mains water from water storage tanks. Alternatively DCUs may be supplied by water from reservoir bottles. Supply water of consistent good quality is imperative for all DCUs. Pretreatment of supply water using a variety of filters customized to suit the water supply characteristics in individual settings can be used to provide DCU supply water of consistent quality and make the subsequent process of DUWL disinfection simpler and more readily achievable. Water supplied to DUWLs should not be heated to discourage the growth of more pathogenic microorganisms such as L. pneumophilia, which preferentially grow at higher temperatures. Finally the development of fully automated, centralized biofilm control systems for simultaneously controlling DUWL biofilm in many DCUs that can provide DUWL output water of consistently better quality than potable water in the long term has provided a robust solution to the problem of DUWL biofilm for dental hospitals and large clinics equipped with many DCUs. It is to be anticipated that further developments with this state-of-the-art biofilm control technology will permit its application for individual DCUs in the near future.

\section{Future perspective}

Contamination of DUWL output water due to proliferation of microbial biofilm seeded primarily from supply water is still a significant problem today. Local pretreatment of water prior to entering storage systems or complex distribution systems is worthwhile in achieving a consistent quality prior to any other more exacting treatments before clinical use. The development of reliable, compact and easily maintained pretreatment units should be a focus of further development and targeted to deal with a wide dynamic range of challenges now seen in many mains water supplies.

Very few long-term studies on the efficacy of chemical DUWL treatment agents have in fact been undertaken $[5,61,62]$. There is also significant potential with some agents for adverse effects on DCU components and human tissues. Recently, some DCU manufacturers have developed validated, integrated and semiautomated DUWL disinfection systems using proven efficacy chemical treatments for control of DUWL biofilms in the long term. This has made significant inroads into providing a permanent solution to the problem for individual DCUs. Recently, the successful development of a fully automated biofilm management system that consistently maintains the quality of DCU supply water and DUWL output water at better than potable quality in the long term by using selected filtration and using low Trustwater Ecasol concentrations to minimize microbial growth has already provided a robust solution to the problem of DUWL biofilm for dental hospitals and clinics equipped with multiple DCUs. It is to be confidently anticipated that adaptations and further developments to this technology for use with individual DCUs will provide a robust solution to the problem of DUWL biofilm in the next few years. The key to the success of this approach relies on the combination of automated provision of consistent quality DCU supply water and DUWL output water quality with no adverse effects on DCU components or on human tissues, and the fact that the technology is environmentally friendly, does not use toxic chemicals or yield toxic effluent in wastewater, is very cost effective and low maintenance. It is to be anticipated that more DCU manufacturers will develop and validate automated DUWL biofilm control technology for their DCUs and provide expert guidance and compact equipment for supply water pretreatment, which is site-specific and tailored to the requirements of individual clinics. To arrive at this point will require more detailed studies on water quality monitoring, biofilm affinity for materials used in DUWLs and biofilm control parameters. Advances made in the dental context will have benefits for many other clinical applications. 
Financial \& competing interests disclosure
The authors have no relevant affliations or financial
involvement with any organization or entity with a
financial interest in or financial conflict with the sub-
ject matter or materials discussed in the manuscript.
This includes employment, consultancies, honoraria, stock ownership or options, expert testimony, grants or patents received or pending, or royalties.

No writing assistance was utilized in the production of this manuscript.

\section{Executive summary}

\section{Dental unit waterlines}

- Dental chair units (DCUs) are equipped with several meters of interconnected narrow bore dental unit waterlines (DUWLs) to provide water to cool DCU-supplied instruments and to irrigate tooth surfaces during instrument use.

- DUWLs are universally prone to microbial biofilm contamination resulting in heavily contaminated DUWL output water, especially with bacteria.

\section{Causes of biofilm contamination of DUWLs}

- Water flow in DUWLs is laminar and accordingly a thin layer of immobile water exists at the lumen surface in which there is little disturbance to microorganisms present.

- Water stagnation in DUWLs when DCUs are not in use encourages the proliferation of biofilm.

- Failure of antiretraction valves in dental instruments can result in retraction of oral fluids into DUWLs expanding the range of microorganisms in DUWL biofilm.

- DUWLs supplied with water from independent reservoir bottles are prone to contamination by skin bacteria during filling, adding further human microorganisms to DUWL biofilm.

\section{Microorganisms found in DUWL output water}

- Environmental Gram-negative, aerobic heterotrophic bacterial species are the predominant microorganisms found in DUWL biofilm and output water.

- Bacterial species of concern for immunocompromised patients include Legionella spp., Pseudomonas aeruginosa and non-tuberculosis Mycobacterium spp.

- Yeasts, fungi, protozoa and amoebae may also be present, but in significantly lower numbers than bacteria.

\section{Evidence for disease associated with contaminated DUWLs}

- Only a few cases of infection associated with contaminated DUWL output water have been described.

- Occupational exposure to DUWL output water can result in dental staff having elevated serum antibodies to Legionella spp.

- Occupational exposure to endotoxin from DUWL output water has been associated with the onset of asthma in a subgroup of dentists.

\section{Control of DUWL biofilm}

- Nonchemical approaches for controlling DUWL biofilm including flushing, the use of sterile, deionized or distilled water, DUWL drying and the use of antimicrobial filters are ineffective.

- A wide range of chemical disinfectants, biocides and cleaning agents used either periodically or continuously have been used to treat DUWL biofilm, with varying success. Hydrogen peroxide-containing products and electrochemically activated solutions are among the most consistently effective.

- DCUs equipped with semiautomated DUWL cleaning systems facilitate and simplify DUWL biofilm control when used with a treatment agent that effectively removes biofilm.

- Biofilm reforms rapidly in DUWLs following disinfection with an intermittent treatment agent.

- Residual DUWL treatment agents can be very effective at controlling biofilm, but patients are exposed to such residual agents, and for many of which independent studies demonstrating biosafety are lacking.

- For dental hospitals and large dental clinics, a centralized and automated biofilm management system that consistently maintains DUWL output water at better than potable quality, simultaneously in many DCUs, is the best option.

\section{Bibliography}

Papers of special note have been highlighted as:

- of interest

-" of considerable interest

1. Francolini I, Donelli G. Prevention and control of biofilm-based medical-devicerelated infections. FEMS Immunol. Med. Microbiol. 59(3), 227-238 (2010).

- A comprehensive overview of medicaldevice-associated infections linked with devices contaminated with biofilms.
2. Donlan RM. Biofilms elimination on intravascular catheters: important considerations for the infectious disease practitioner. Clin. Infect. Dis. 52(8), 1038-1045 (2011).

3. Coleman DC, O’Donnell MJ, Shore AC, Russell RJ. Biofilm problems in dental unit water systems and its practical control. J. Appl. Microbiol. 106(5), 1424-1437 (2009).

4. Han J, Liu Y. Effect of ventilator circuit changes on ventilator-associated pneumonia: a systematic review and meta-analysis. Respir. Care. 55(4), 467-474 (2010).
5. Coleman DC, O'Donnell MJ, Shore AC, Swan J, Russell RJ. The role of manufacturers in reducing biofilms in dental chair waterlines. J. Dent. 35(9), 701-711 (2007).

-. A comprehensive review of the role and contributions of dental chair unit (DCU) manufacturers in providing solutions to the problem of dental unit waterline (DUWL) biofilms.

6. No authors listed. Council Directive 93/42/ EEC of 14 June 1993 Concerning Medical 
Devices. Official Journal of the European Communities L169, 1-43 (1993).

7. Siegel SC, von Fraunhofer JA. The effect of handpiece spray patterns on cutting efficiency. J. Am. Dent. Assoc. 133(2), 184-188 (2002).

8. Blake GC. Incidence and control of bacterial infection in dental spray reservoirs. Br. Dent. J. 115, 413-416 (1963).

9. Belting CM, Haberfelde GC, Juhl LK. Spread of organisms from dental air rotor. J. Am. Dent. Assoc. 68, 648-651 (1964).

10. Abel LC, Miller RL, Micik RE, Ryge G. Studies on dental aerobiology: IV. Bacterial contamination of water delivered by dental units. J. Dent. Res. 50(6), 1567-1569 (1971).

11. McEntegart MG, Clark A. Colonisation of dental units by water bacteria. $B r$. Dent. J. 134(4), 140-142 (1973).

12. Clark A. Bacterial colonization of dental units and the nasal flora of dental personnel. Proc. R. Soc. Med. 67(12 Pt 1), 1269-1270 (1974).

13. Gross A, Devine MJ, Cutright DE. Microbial contamination of dental units and ultrasonic scalers. J. Periodontol. 47(11), 670-673 (1976).

14. Kelstrup J, Funder-Nielsen TD, Theilade J. Microbial aggregate contamination of water lines in dental equipment and its control. Acta Pathol. Microbiol. Scand. B. 85(3), 177-183 (1977).

15. Dayoub MB, Rusilko DJ, Gross A. A method of decontamination of ultrasonic scalers and high speed handpieces. J. Periodontol. 49(5), 261-265 (1978).

16. Kellett M, Holbrook WP. Bacterial contamination of dental handpieces. J. Dent. 8(3), 249-253 (1980).

17. Scheid RC, Kim CK, Bright JS, Whitely MS, Rosen S. Reduction of microbes in handpieces by flushing before use. J. Am. Dent. Assoc. 105(4), 658-660 (1982).

18. Fitzgibbon EJ, Bartzokas CA, Martin MV, Gibson MF, Graham R. The source, frequency and extent of bacterial contamination of dental unit water systems. Br. Dent. J. 157(3), 98-101 (1984).

19. Furuhashi M, Miyamae T. Prevention of bacterial contamination of water in dental units. J. Hosp. Infect. 6(1), 81-88 (1985).

20. Martin MV. The significance of the bacterial contamination of dental unit water systems. $\mathrm{Br}$. Dent. J. 163(5), 152-154 (1987).

- This study was the first to report a direct association between infection in patients following dental treatment with DCUs yielding contaminated DUWL output water.

21. Mayo JA, Oertling KM, Andrieu SC. Bacterial biofilm: a source of contamination in dental air-water syringes. Clin. Prev. Dent. 12(2), 13-20 (1990).
22. Pankhurst CL, Philpott-Howard JN. The microbiological quality of water in dental chair units. J. Hosp. Infect. 23(3), 167-174, (1993).

23. Williams JF, Johnston AM, Johnson B, Huntington MK, Mackenzie CD. Microbial contamination of dental unit waterlines: prevalence, intensity and microbiological characteristics. J. Am. Dent. Assoc. 124(10), 59-65 (1993).

24. Barbeau J, Tanguay R, Faucher E et al. Multiparametric analysis of waterline contamination in dental units. Appl. Environ. Microbiol. 62(11), 3954-3959 (1996).

25. Pankhurst CL, Johnson NW, Woods RG. Microbial contamination of dental unit waterlines: the scientific argument. Int. Dent. J. 48(4), 359-368 (1998).

26. Mills SE. The dental unit waterline controversy: defusing the myths, defining the solutions. J. Am. Dent. Assoc. 131(10), 1427-1441 (2000).

27. Walker JT, Bradshaw DJ, Bennett AM, Fulford MR, Martin MV, Marsh PD. Microbial biofilm formation and contamination of dental-unit water systems in general dental practice. Appl. Environ. Microbiol. 66(8), 3363-3367 (2000).

28. Putnins EE, Di Giovanni D, Bhullar AS. Dental unit waterline contamination and its possible implications during periodontal surgery. J. Periodontol. 72(3), 393-400 (2001).

29. Tuttlebee CM, O'Donnell MJ, Keane CT et al. Effective control of dental chair unit waterline biofilm and marked reduction of bacterial contamination of output water using two peroxide-based disinfectants. J. Hosp. Infect. 52(3), 192-205 (2002).

30. Walker JT, Bradshaw DJ, Fulford MR, Marsh PD. Microbiological evaluation of a range of disinfectant products to control mixed-species biofilm contamination in a laboratory model of a dental unit water system. Appl. Environ. Microbiol. 69(6), 3327-3332 (2003).

31. Walker JT, Marsh PD. A review of biofilms and their role in microbial contamination of dental unit water systems (DUWS). Int. Biodeter. Biodegr. 54(2-3), 87-98 (2004).

32. Pasquarella C, Veronesi L, Castiglia $\mathrm{P}$ et al. Italian multicentre study on microbial environmental contamination in dental clinics: a pilot study. Sci. Total Environ. 408(19), 4045-4051 (2010).

33. Lin SM, Svoboda KK, Giletto A, Seibert J, Puttaiah R. Effects of hydrogen peroxide on dental unit biofilms and treatment water contamination. Eur. J. Dent. 5(1), 47-59 (2011).
34. Costerton JW. The Biofilm Primer. Ecckey C (Ed.), Springer-Verlag, Berlin, Germany, (2007).

- A comprehensive introduction to the biology, characteristics and behavior of biofilms.

35. Shearer BG. Biofilm and the dental office. J. Am. Dent. Assoc. 127(8), 181-189 (1996).

36. Wirthlin MR, Marshall GW Jr, Rowland EW. Formation and decontamination of biofilms in dental unit waterlines. J. Periodontol. 74(11), 1595-1609 (2003).

37. Davey ME, O'Toole GA. Microbial biofilms: from ecology to molecular genetics. Microbiol. Mol. Biol. Rev. 64(4), 847-867 (2000).

38. Watnick P, Kolter R. Biofilm, city of microbes. J. Bacteriol. 182(10), 2675-2679 (2000).

39. Purevdorj B, Costerton JW, Stoodley P. Influence of hydrodynamics and cell signaling on the structure and behavior of Pseudomonas aeruginosa biofilms. Appl. Environ. Microbiol. 68(9), 4457-4464 (2002).

40. Fotos PG, Westfall HN, Snyder IS, Miller RW, Mutchler BM. Prevalence of Legionella-specific IgG and IgM antibody in a dental clinic population. J. Dent. Res. 64(12), 1382-1385 (1985).

41. Reinthaler FF, Mascher F, Stünzner D. Serological examinations for antibodies against Legionella species in dental personnel. J. Dent. Res. 67(6), 942-943 (1988).

42. Atlas RM, Williams JF, Huntington MK. Legionella contamination of dental-unit waters. Appl. Environ. Microbiol. 61(4), 1208-1213 (1995).

- Investigated a possible link between the death of a dentist in California from legionellosis and Legionella-contaminated DUWL output water from the dentist's DCU.

43. Denton M, Todd NJ, Kerr KG, Hawkey PM, Littlewood JM. Molecular epidemiology of Stenotrophomonas maltophilia isolated from clinical specimens from patients with cystic fibrosis and associated environmental samples. J. Clin. Microbiol. 36(7), 1953-1958 (1998).

44. Williams HN, Johnson A, Kelley JI et al. Bacterial contamination of the water supply in newly installed dental units. Quintessence Int. 26(5), 331-337 (1995).

45. Barbeau J, Tanguay R, Faucher E et al. Multiparametric analysis of waterline contamination in dental units. Appl. Environ. Microbiol. 62(11), 3954-3959 (1996). 
46. Wadowsky RM, Wolford R, McNamara AM, Yee RB. Effect of temperature, $\mathrm{pH}$, and oxygen level on the multiplication of naturally occurring Legionella pneumophila in potable water. Appl. Environ. Microbiol. 49(5), 1197-1205 (1985).

47. Stampi S, Zanetti F, Bergamaschi A, De Luca G. Comamonas acidovorans contamination of dental unit waters. Lett. Appl. Microbiol. 29(1), 52-55 (1999).

48. Berlutti F, Testarelli L, Vaia F, De Luca M, Dolci G. Efficacy of anti-retraction devices in preventing bacterial contamination of dental unit water lines. J. Dent. 31(2), 105-100 (2003).

- Demonstrated a high failure rate of antiretraction devices in a range of DCUs and thus showed significant potential for contamination of DUWLs by retraction of oral fluids into DUWLs.

49. Montebugnoli L, Chersoni S, Prati C, Dolci G. A between-patient disinfection method to control water line contamination and biofilm inside dental units. J. Hosp. Infect. 56(4), 297-304 (2004).

50. Petti S, Tarsitani G. Detection and quantification of dental unit water line contamination by oral streptococci. Infect. Control Hosp. Epidemiol. 27(5), 504-509 (2006).

51. Ohara-Nemoto Y, Haraga H, Kimura S, Nemoto TK. Occurrence of staphylococci in the oral cavities of healthy adults and nasal oral trafficking of the bacteria. J. Med. Microbiol. 57(1), 95-99 (2008).

52. Humphreys H, Keane CT, Hone R et al. Enterotoxin production by Staphylococcus aureus isolates from cases of septicaemia and from healthy carriers. J. Med. Microbiol. 28(3), 163-172 (1989).

53. Coleman DC, Pomeroy H, Estridge JK et al. Susceptibility to antimicrobial agents and analysis of plasmids in gentamicin- and methicillin-resistant Staphylococcus aureus from Dublin hospitals. J. Med. Microbiol. 20(2), 157-167 (1985).

54. Carroll D, Kehoe MA, Cavanagh D, Coleman DC. Novel organization of the site-specific integration and excision recombination functions of the Staphylococcus aureus serotype F virulenceconverting phages phi 13 and phi 42. Mol. Microbiol. 16(5), 877-893 (1995).

55. Rossney AS, Shore AC, Morgan PM, Fitzgibbon MM, O’Connell B, Coleman DC. The emergence and importation of diverse genotypes of methicillin-resistant Staphylococcus aureus (MRSA) harboring the Panton-Valentine leukocidin gene $(p v l)$ reveal that $p v l$ is a poor marker for community-acquired MRSA strains in Ireland. J. Clin. Microbiol. 45(8), 2554-2556 (2007).

56. Artini M, Scoarughi GL, Papa R et al. Specific anti cross-infection measures may help to prevent viral contamination of dental unit waterlines: a pilot study. Infection 36(5), 467-471 (2008).

- Demonstrated the presence of hepatitis C virus (HCV) RNA in DUWLs following dental treatment of $\mathrm{HCV}$-infected patients using DCUs without antiretraction devices or with defective antiretraction devices.

57. Kohn WG, Collins AS, Cleveland JL, Harte JA, Eklund KJ, Malvitz DM. Centers for Disease Control and Prevention (CDC). Guidelines for infection control in dental health-care settings - 2003.

Recommendations and reports. $M M W R$ 52(RR-17), 1-61 (2003).

58. Lancellotti M, de Oliveira MP, de Ávila FA. Research on Staphylococcus species in biofilm formation in water pipes and sensibility to antibiotics. Braz. J. Oral Sci. 6(20), 1283-1288 (2007).

59. Coleman DC, O’Donnell, MJ, Boyle M, Russell R. Microbial biofilm control within the dental clinic: reducing multiple risks. Journal of Infection Prevention 11(6), 192-198 (2010).

60. Singh R, Stine OC, Smith DL, Spitznagel JK Jr, Labib ME, Williams HN. Microbial diversity of biofilms in dental unit water systems. Appl. Environ. Microbiol. 69(6), 3412-3420 (2003).

61. O’Donnell MJ, Shore AC. Coleman DC. A novel automated waterline cleaning system that facilitates effective and consistent control of microbial biofilm contamination of dental chair unit waterlines: a one-year study. J. Dent. 34(9), 648-661 (2006).

- The first long-term study of an automated DUWL disinfection system integrated in DCUs to consistently provide good quality DUWL output water using a periodic DUWL treatment agent that effectively controls DUWL biofilm.

62. O’Donnell MJ, Shore AC, Russell RJ, Coleman DC. Optimisation of the long-term efficacy of dental chair waterline disinfection by the identification and rectification of factors associated with waterline disinfection failure. J. Dent. 35(5), 438-451 (2007).

.-This study demonstrated that human error, adverse effects of DUWL chemical treatment agents on DCU components and selection of disinfectant-tolerant bacterial species can all contribute to DUWL disinfection failure.
63. Pankhurst CL, Coulter WA. Do contaminated dental unit waterlines pose a risk of infection? J. Dent. 35(9), 712-720 (2007).

- A comprehensive overview of potential infection risks associated with exposure to contaminated DUWL output water.

64. Porteous NB, Redding SW, Thompson EH, Grooters AM, De Hoog S, Sutton DA. Isolation of an unusual fungus in treated dental unit waterlines. J. Am. Dent. Assoc. 134(7), 853-858 (2003).

65. Singh T, Coogan MM. Isolation of pathogenic Legionella species and Legionellaladen amoebae in dental unit waterlines. J. Hosp. Infect. 61(3), 257-262 (2005).

66. Szymanska J. Evaluation of mycological contamination of dental unit waterlines. Ann. Agric. Environ. Med. 12(1), 153-155 (2005)

67. Göksay D, Cotuk A, Zeybek Z. Microbial contamination of dental unit waterlines in Istanbul, Turkey. Environ. Monit. Assess. 147(1-3), 265-269 (2008).

68. Schulze-Röbbecke R, Feldmann C, Fischeder R, Janning B, Exner M, Wahl G. Dental units: an environmental study of sources of potentially pathogenic mycobacteria. Tuber. Lung Dis. 76(4), 318-323, (1995).

69. Porteous NB, Redding SW, Jorgensen JH. Isolation of non-tuberculosis mycobacteria in treated dental unit waterlines. Oral Surg. Oral. Med. Oral. Pathol. Oral. Radiol. Endod. 98(1), 40-44, (2004).

70. Dutil S, Veillette M, Mériaux A, Lazure L, Barbeau J, Duchaine C. Aerosolization of mycobacteria and legionellae during dental treatment: low exposure despite dental unit contamination. Environ. Microbiol. 9(11), 2836-2843 (2007)

71. Tanzi ML, Capobianco E, Affanni P, Pizzi S, Vitali P, Veronesi L. Legionella species in hospital dental facilities. J. Hosp. Infect. 63(2), 232-234 (2006).

72. Veronesi L, Capobianco E, Affanni P, Pizzi S, Vitali P, Tanzi ML. Legionella contamination in the water system of hospital dental settings. Acta Biomed. 78(2), 117-122 (2007).

73. Barbeau J, Buhler T. Biofilms augment the number of free-living amoebae in dental unit waterlines. Res Microbiol. 152(8), 753-760 (2001).

74. Borella P, Bargellini A, Marchesi I et al., Prevalence of anti-Legionella antibodies among Italian hospital workers. J. Hosp. Infect. 69(2), 148-155 (2008).

- Demonstrated that dental workers had a higher sero-prevalence of antibodies against Legionella than office workers, 
possibly due to exposure to DUWL output water contaminated with Legionella bacteria.

75. Barbeau J. Lawsuit against a dentist related to serious ocular infection possibly linked to water from a dental handpiece. J. Can. Dent. Assoc. 73(7), 618-622 (2007).

76. Singh TS, Bello B, Mabe OD, Renton K, Jeebhay MF. Workplace determinants of endotoxin exposure in dental healthcare facilities in South Africa. Ann. Occup. Hyg. 54(3), 299-308 (2010).

77. Michel O, Kips J, Duchateau J et al. Severity of asthma is related to endotoxin in house dust. Am. J. Respir. Crit. Care. Med. 154 (6 Pt 1), 1641-1646 (1996).

78. Pankhurst CL, Coulter W, Philpott-Howard JN, Surman-Lee S, Warburton F, Challacombe S. Evaluation of the potential risk of occupational asthma in dentists exposed to contaminated dental unit waterlines. Prim. Dent. Care. 12(2), 53-59 (2005).

-. This study identified a temporal association between occupational exposure to contaminated DUWL output water and development of asthma in a subgroup of dentists in whom asthma arose following the commencement of dental training.

79. Anonymous. Council Directive $98 / 83 / \mathrm{EC}$ of 3 November 1998 on the Quality of Water Intended for Human Consumption. Official Journal of the European Union L330, 32-54 (1998).

80. O’Donnell MJ, Boyle M, Swan J, Russell RJ, Coleman DC. A centralised, automated dental hospital water quality and biofilm management system using neutral Ecasol maintains dental unit waterline output at better than potable quality: a 2 -year longitudinal study. J Dent. 37(10), 748-762 (2009).

-. The authors describe a long-term study of a fully automated biofilm management system using the $\mathrm{pH}$ neutral electrochemically activated solution Ecasol $^{\mathrm{TM}}$ that consistently maintains the quality of DCU supply water and DUWL output water at better than potable quality simultaneously in over 100 DCUs.

81. Flemming HC. Biofouling in water systemscases, causes and countermeasures. Appl. Microbiol. Biotechnol. 59(6), 629-640 (2002).

82. Souza-Gugelmin MC, Lima CD, Lima SN, Mian H, Ito IY. Microbial contamination in dental unit waterlines. Brazilian Dental J. 14(1), 55-57 (2003).

83. No authors listed. ADA statement on dental unit waterlines. J. Am. Dent. Assoc. 127 (8),188-189 (1996).
84. Coleman DC, and O'Donnell MJ. Guest editorial. J. Dent. 35(9), 699-700 (2007).

85. Rice EW, Rich WK, Johnson CH, Lye DJ. The role of flushing dental water lines for the removal of microbial contaminants. Public Health Rep. 121(3), 270-274 (2006).

86. Fiehn NE, Larsen T. The effect of drying dental unit waterline biofilms on the bacterial load of dental unit water. Int. Dent. J. $52(4)$, 251-254 (2002).

87. Pankhurst CL, Philpott-Howard JN, Hewitt JH, Casewell MW. The efficacy of chlorination and filtration in the control and eradication of Legionella from dental chair water systems. J. Hosp. Infect. 16(1), 9-18 (1990).

88. Murdoch-Kinch CA, Andrews NL, Atwan S, Jude R, Gleason MJ, Molinari JA. Comparison of dental water quality management procedures. J. Am. Dent. Assoc. 128(9), 1235-1243 (1997).

89. Copenhagen TL. The effect of ultrafiltration on the quality of water from dental units. Int. Dent. J. 56(6), 352-355 (2006).

90. Yabune T, Imazato S, Ebisu S. Inhibitory effect of PVDF tubes on biofilm formation in dental unit waterlines. Dent. Mater. 21(8), 780-786 (2005).

91. Walker JT, Marsh PD. Microbial biofilm formation in DUWS and their control using disinfectants. J. Dent. 35(9), 721-730 (2007).

- A comprehensive overview of biofilm formation in DUWLs and chemical treatment agents used to control them.

92. Mills SE. The dental unit waterline controversy: defusing the myths, defining the solutions. J. Am. Dent. Assoc. 131(10), 1427-1441 (2000).

93. McDowell JW, Paulson DS, Mitchell JA. A simulated-use evaluation of a strategy for preventing biofilm formation in dental unit waterlines. J. Am. Dent. Assoc. 135(6), 799-805 (2004).

94. Spratt DA, Latif J, Montebugnoli LL, Wilson M. In vitro modeling of dental water line contamination and decontamination. FEMS Microbiol. Lett. 235(2), 363-367 (2004).

95. Schel AJ, Marsh PD, Bradshaw DJ et al. Comparison of the efficacies of disinfectants to control microbial contamination in dental unit water systems in general dental practices across the European Union. Appl. Environ. Microbiol. 72(2), 1380-1387 (2006).

- A large-scale study in DCUs of the efficacy of disinfectants to control contamination of DUWL output water. The study showed that hydrogen peroxide-containing products were particularly effective and that residual products performed better than products used periodically.

96. Walker JT, Bradshaw DJ, Bennett AM, Fulford MR, Martin MV, Marsh PD. Microbial biofilm formation and contamination of dental-unit water systems in general dental practice. Appl. Environ. Microbiol. 66(8), 3363-3367 (2000).

97. Kohno S, Kawata T, Kaku M et al. Bactericidal effects of acidic electrolyzed water on the dental unit waterline. Jpn J. Infect. Dis. 57(2), 52-54 (2004).

98. Martin MV, Gallagher MA. An investigation of the efficacy of super-oxidised (Optident/Sterilox) water for the disinfection of dental unit water lines. Br. Dent. J. 198(6), 353-354 (2005).

99. Zhang W, Onyango O, Lin Z, Lee SS, Li Y. Evaluation of Sterilox for controlling microbial biofilm contamination of dental water. Compend. Contin. Educ. Dent. 28(11), 586-588 (2007).

100. Boyle MA, O’Donnell MJ, Russell RJ, Coleman DC. Lack of cytotoxicity by Trustwater Ecasol ${ }^{\mathrm{TM}}$ used to maintain good quality dental unit waterline output water in keratinocyte monolayer and reconstituted human oral epithelial tissue models. J. Dent. 38(11), 930-940 (2010).

- One of the few independent studies to demonstrate the biosafety of a residual DUWL treatment agent.

101. O’Donnell MJ, Tuttlebee CM, Falkiner FR, Coleman DC. Bacterial contamination of dental chair units in a modern dental hospital caused by leakage from suction system hoses containing extensive biofilm. J. Hosp. Infect. 59(4), 348-360 (2005).

102. Fan PL, Batchu H, Chou HN, Gasparac W, Sandrik J, Meyer DM. Laboratory evaluation of amalgam separators. J. Am. Dent. Assoc. 133(5), 577-584 (2002).

103. Stone ME, Kuehne JC, Cohen ME, Talbott JL, Scott JW. Effect of iodine on mercury concentrations in dental-unit wastewater. Dent. Mater. 22(2), 119-124 (2006).

104. Hammarback B, Mills S, Johnson R. Re: Stone et al.'s "effect of iodine on mercury concentrations in dental-unit wastewater". Dent. Mater. 23(12), 1590-1592 (2007).

105. Roberts HW, Marek M, Kuehne JC, Ragain JC. Disinfectants' effect on mercury release from amalgam. J. Am. Dent. Assoc. 136(7), 915-919 (2005).

106. Batchu H, Chou HN, Rakowski D, Fan PL. The effect of disinfectants and line cleaners on the release of mercury from amalgam. J. Am. Dent. Assoc. 137(10), 1419-1425 (2006). 
107. Roberts HW, Karpay RI, Mills SE. Dental unit waterline antimicrobial agents' effect on dentin bond strength. J. Am. Dent. Assoc. 131(2), 179-183 (2000).

108. Taylor-Hardy TL, Leonard RH Jr, Mauriello SM, Swift EJ Jr. Effect of dental unit waterline biocides on enamel bond strengths. Gen. Dent. 49(4), 421-425 (2001).

109. Szymanska J. Bacterial decontamination of DUWL biofilm using Oxygenal 6. Ann. Agric. Environ. Med. 13(1), 163-167 (2006).

110. Mills SE, Lauderdale PW, Mayhew RB. Reduction of microbial contamination in dental units with povidone-iodine $10 \%$. J. Am. Dent. Assoc. 113(2), 280-284 (1986).

111. Depaola LG, Mangan D, Mills SE et al. A review of the science regarding dental unit waterlines. J. Am. Dent. Assoc. 133(9), 1199-1206 (2002).

112. Kettering JD, Muñoz-Viveros CA, Stephens JA, Naylor WP, Zhang W. Reducing bacterial counts in dental unit waterlines: distilled water vs. antimicrobial agents. J. Calif. Dent. Assoc. 30 (10), 735-741 (2002).

113. Al-Hiyasat AS, Ma'ayeh SY, Hindiyeh MY, Khader YS. The presence of Pseudomonas aeruginosa in the dental unit waterline systems of teaching clinics. Int. J. Dent. Hyg. 5(1), 36-44 (2007).

114. Watanabe E, Agostinho AM, Matsumoto W, Ito I. Dental unit water: bacterial decontamination of old and new dental units by flushing water. Int. J. Dent. Hyg. 6(1), 56-62 (2008).
115. Ozcan M, Kulak Y, Kazazoglu E. The effect of disinfectant agents in eliminating the contamination of dental unit water. J. Oral Rehabil. 30(3), 290-294 (2003).

116. Wirthlin MR, Marshall GW Jr. Evaluation of ultrasonic scaling unit waterline contamination after use of chlorine dioxide mouthrinse lavage. J. Periodontol. 72(3), 401-410 (2001).

117. Smith AJ, Bagg J, Hood J. Use of chlorine dioxide to disinfect dental unit waterlines. J. Hosp. Infect. 49(4), 285-288 (2001).

118. Douglas CW, Rothwell PS. Evaluation of a dental unit with a built-in decontamination system. Quintessence Int. 22(9), 721-726 (1991).

119. Gigola P, Angelillo V, Garusi G. Effectiveness of a glutaraldehyde formulation in decontamination of dental unit water systems. Minerva Stomatol. 55(7-8), 437-448 (2006).

120. Fiehn NE, Henriksen K. Methods of disinfection of the water system of dental units by water chlorination. J. Dent. Res. 67(12), 1499-1504 (1988).

121. Karpay RI, Plamondon TJ, Mills SE, Dove SB. Combining periodic and continuous sodium hypochlorite treatment to control biofilms in dental unit water systems. J. Am. Dent. Assoc. 130 (7), 957-965 (1999).

122. Kim PJ, Cederberg RA, Puttaiah R. A pilot study of 2 methods for control of dental unit biofilms. Quintessence Int. 31(1), 41-48 (2000).
123. Linger JB, Molinari JA, Forbes WC, Farthing CF, Winget WJ. Evaluation of a hydrogen peroxide disinfectant for dental unit waterlines. J. Am. Dent. Assoc. 132(9), 1287-1291 (2001).

124. Shepherd PA, Shojaei MA, Eleazer PD, Van Stewart A, Staat RH. Clearance of biofilms from dental unit waterlines through the use of hydroperoxide ion-phase transfer catalysts. Quintessence Int. 32(10), 755-761 (2001).

125. Larsen T, Fiehn NE. The effect of Sterilex Ultra for disinfection of dental unit waterlines. Int. Dent. J. 53(4), 249-254 (2003).

126. Percival RS, Devine DA, Nattress B, Kite P, Marsh PD. Control of microbial contamination in dental unit water systems using tetra-sodium EDTA. J. Appl. Microbiol. 107(4), 1081-1088 (2009).

127. Smith AJ, McHugh S, Aitken I, Hood J. Evaluation of the efficacy of Alpron disinfectant for dental unit water lines. $B r$. Dent. J. 193(10), 593-596 (2002).

\section{Websites}

201. National primary drinking water standards. United States Environmental Protection Agency May 2011 http://water.epa.gov/drink/contaminants/ index.cfm (Accessed 26 July 2011)

202. ADA Statement on Dental Unit Waterlines July 2004 www.ada.org/1856.aspx (Accessed 26 July 2011) 